$\Phi=$

\title{
Immune evasion in colo-rectal cancer in a cohort of Sudanese patients: possible roles for MHC Class II antigens
}

\author{
Mohammed MM Dafalla ${ }^{1 *}$, Kamal Elzaki Elssidig ${ }^{2}$, Elsagad E A Mohamed ${ }^{3}$, Mohamed E M O Elsafi ${ }^{4}$, \\ Hatim A A Mohammed ', Brima M Younis ${ }^{1}$, Chantal van Niekerk ${ }^{5}$, Vanessa Steenkamp ${ }^{6}$, \\ Ahmed M Musa ${ }^{1}$, Eltahir A G Khalil ${ }^{1}$ \\ ${ }^{1}$ Department of Clinical Pathology \& Immunology, Institute of Endemic Diseases, University of Khartoum \\ ${ }^{2}$ Department of Surgery, Faculty of Medicine, University, University of Khartoum. The Medical campus \\ ${ }^{3}$ Ibn Sina Specialized Hospital, Khartoum \\ ${ }^{4}$ Department of Pathology, Faculty of Medicine, National Ribat University \\ ${ }^{5}$ Department of Chemical Pathology, Faculty of Health Sciences, University of Pretoria/NHLS, \\ Senior Medical Scientist Dept Chemical Pathology University of Pretoria / NHLS \\ ${ }^{6}$ Department of Pharmacology, Faculty of Health Sciences, University of Pretoria, \\ Postal address: Dept of Pharmacology Private Bag x323 Arcadia 0007, South Africa \\ *Corresponding author E-mail: mohadafalla@gmail.com
}

\begin{abstract}
Background: Colorectal cancer (CRC) is the third most common cancer world-wide. The majority of cases occur in the developed world. This prospective study aimed to correlate different human leukocyte antigens (HLA types; HLA DRB1 and DRB3) with the aggressiveness of CRC in Sudanese patients.

Methods: Thirty-three patients with histopathologically confirmed CRC were included in the study. Demographic, clinical and laboratory data were recorded. Molecular typing for HLA DRB1 (DR1, 7 and 17), DRB3 and DRB4 were carried out using PCR-based Sequence-Specific Primers.

Results: Forty percent of the patients were $\leq 50$ years; with a male to female ratio of 2.5:1. Rectal bleeding was the commonest presenting symptom. While moderately differentiated adenocarcinoma was the dominant histological type. Duke's stages B and C were reported in $54.6 \%$ and $42.4 \%$ of patients, respectively. No patients presented with Dukes stages A or D. HLA DRB3 was the most frequent allele detected followed by DRB4 and DR17. A higher frequency of the DRB3 allele was found in the peripheral blood when compared with the tumor and apparently normal tissues. HLA DRB3 and DR7 allele frequencies correlated with Duke's stages B and C but not with age, sex or degree of differentiation, while blood DR17 antigen correlated only with the degree of tumor differentiation.

Conclusion: CRC was found to have a higher occurrence in younger patients. Tumors were aggressive with advance Duke's stage at presentation. This aggressive nature could possibly be related to either increased HLA DRB3 or DR7 or decreased HLA DR17 levels in the tumor tissue when compared with the blood. No differences between tumor and normal colon tissues were found, in concordance with the multifocally of colon cancer theory.
\end{abstract}

Keywords: Aggressive Colo-Rectal Cancer; MHC Class II Antigens; Sudan.

\section{Introduction}

Cancer is the leading cause of death in economically developed countries and the second-leading cause of death in developing countries. (WHO.2008). Despite this, cancer is considered as a lower health priority in Africa compared with other continents. (Siegel R et al.2012). Sudan is no exception as health policies in the country are mainly focused on infectious diseases. According to the National Centre for Health Statistic report, colorectal cancer (CRC) is the third most commonly diagnosed cancer and the thirdleading cause of deaths in the USA. (Matanoski G et al.2006). There is limited statistical data on CRC in Sudan. Neither has molecular and immunological characterization of CRC in Sudanese patients been carried out to our knowledge. The first National Cancer Registry in Sudan was established in 2009. It was deter- mined that CRC was the fifth most registered cancer in Khartoum with a rate of 7.1 per 100.000. (Saeed E et al.2014).

The immune system plays an important role in tumor growth and metastasis. (Menon A et al.2004). Evasion and suppression of the immune system are two important abilities that cancer cells acquire during the process of tumorigenesis. (Cavallo F et al.2011). For many decades, CRC has been viewed as an example of a poorly immunogenic tumor; however, recent evidence suggests that there are significant host interactions with this type of cancer. (Shunyakov L et al.2004). This highlighted the presence of immune responses that are associated with improved prognosis, which probably alter the natural history of CRC. (Shunyakov L et al.2004).

The major histocompatibility complex (MHC) antigens have gained interest due to their impact on human diseases. Only recently the role of MHC antigens in cancer has been established, showing that some haplotypes are connected to prognosis and 
survival. (Giuseppe VM et al.2010).Selected patients with unfavorable HLA types might benefit from more radical primary surgery, sentinel node biopsy if applicable and more extensive adjuvant treatments. On the other hand, patients with favourable haplotypes can be identified in earlier stages before the development of metastatic disease and thereby provide a larger window of opportunity for early intervention, intensive follow-up, and aggressive treatment. (Giuseppe $\mathrm{S}$ et al.2014).

MHC class II antigens can be conditionally expressed by all cell types, but are normally expressed only on professional antigenpresenting cells (APCs): macrophages, B cells and especially dendritic cells (DCs). MHC class II molecules are also expressed by a variety of malignant tumors of different embryological origin. (Daar AS et al.1984). The highest frequency of these molecules has been reported in renal cell carcinoma (De Bruin EC et al.2008), medullary breast carcinoma (Lazzaro B et al.2001)and melanomas. (Taramelli D et al.1986).

Conflict information is available about the clinical significance of MHC class II antigen expression in CRC tumor tissues. MHC class II antigen expression in CRC tumors tissues has been reported to be associated with favourable prognosis. (De Bruin EC et al.2008), (Lovig $\mathrm{T}$ et al.2006).Others al .2006). Others unfavourable unfavorable where it it has shown MHC class II antigens expression in CRC cells was not associated with the clinical course of the disease (Moller P et al.1991, Mulder WM et al.1997, Diederichsen A et al.2003).

Information about MHC class II antigen expression in CRC tumor tissues and its clinical significance may contribute to our understanding of the role of these molecules in the interactions of CRC tumors with the host's immune system to design new strategies to modulate these interactions. In the present study, the frequencies of HLA class II antigens in a cohort of Sudanese patients with $\mathrm{CRC}$ were determined. Possible correlations of these antigens with the clinical data and histopathological characteristics of the tumors were also assessed.

\section{Materials and methods}

\subsection{Ethical consideration}

This study was approved by the Ethics and Scientific Committees of the Institute of Endemic Diseases, University of Khartoum. Patients with colorectal cancer diagnosed by colonoscopy and confirmed by histopathology, who were admitted to Ibn Sienna GIT Specialized Centre and Khartoum Teaching Hospital and provided consents were included in the study. Patients younger than 18 years were excluded from the study.

\subsection{Study participant information}

Demographic, clinical and laboratory data were collected on a uniquely designed case record form (CRF) and the IBM-SPSS Statistics version 20 was used for data entry and analysis. Demographic data included age, sex and other parameters.

Clinical information collected included haematological parameters; white blood cell count (4-10 X 109/L), platelet count (130 400 X 109/L), red blood cell count (Male 4.4-5.7 X 1012/, Female 4.0-5.2 X 1012/L) Renal function information included creatinine concentration (Female 50-90 $\mu \mathrm{mol} / \mathrm{L}$, Male $70-120 \mu \mathrm{mol} / \mathrm{L}$ ), sodium level (135-145 $\mathrm{mmol} / \mathrm{L})$ and potassium concentration (3.5-5.0 $\mathrm{mmol} / \mathrm{L})$.

\subsection{Biological specimens}

Blood $(2.5 \mathrm{~mL})$ was collected into EDTA tubes. Tissue was collected from the tumor site and examined post-operatively by a histopathologist. All tissue biopsies were placed in $25 \mathrm{~mL}$ lysis buffer and stored at $-20^{\circ} \mathrm{C}$ until analysis.

\subsection{DNA extraction}

DNA extraction from blood was carried out using the guanidine chloride method modified from Blakwell Laboratories Cambridge UK. (Bruce A et al.1996). DNA from tissue was obtained using the GeneJETTM Genomic DNA Purification Kit (Thermo Scientific) according to the manufacturer's protocol.

DNA concentration was measured and purity was determined using a Nanodrop spectrophotometer (Thermo Scientific, Hudson, New Hampshire 03051, USA). Samples with DNA concentrations above $50 \mathrm{ng} / \mathrm{mL}$ and purity above 1.8 were used for analysis.

PCR amplicons were run on a $1 \%$ agarose gel containing 0.5 $\mu \mathrm{g} / \mathrm{mL}$ ethidium bromide. The gel was visualised under UV light using a FireReader Gel documentation system (Uvitec, UK).

\subsection{Tissue typing}

HLA class II (DRB1, DRB3, DRB4, DRB5) amplification and typing were carried out using HLA-SSP (PCR-based SequenceSpecific Primers) typing kits (Bio-Rad Medical Diagnostics,) according to the manufacturer's instructions.

The presence or absence of the various amplicons was documented.

Characterization of the PCR products was done using Agarose gel electrophoresis (submarine electrophoresis) with the whole volume of the PCR product $(10 \mu \mathrm{L} /$ each well) was loaded into the gel wells and electrophoresis at $100 \mathrm{mV}$ for $20 \mathrm{~min}$. The gel was viewed and photographed on the UV illuminator using Canon (PC 1234), 8 Mega Pexil camera.

Gel results interpretation was based on whether a specific band is present on the gel or not. For evaluation, the pattern of the specific bands is transferred to the result sheet.

\section{Results}

\subsection{Demographical data}

Thirty-three Sudanese patients with histologically confirmed CRC were included in this study. Seventy per cent were male, with a male: female ratio of 2.5:1. The mean patient age was 55.1 \pm 13.5 years, with the youngest patient being 30 years old. The mean age for male patients was $56 \pm 13.2$ years compared to $52 \pm 14.5$ years for females. More than a third $(39.4 \%)$ of the study participants was below the age of fifty. The remaining participants fell in the age group 51-60 years.

\subsection{Clinical data}

With regards to tumor location, $54.5 \%$ were rectal, $18.2 \%$ rectosigmoid, $18.2 \%$ left-sided colon and $9.1 \%$ right-sided colon. The presence of blood in the rectum was the most common presenting symptom (79\%). Weight loss was experienced by $66 \%$ of patients. Constipation, abdominal pain, diarrhea and mucus in the rectum were also reported.

Signs of CRC were present in $21 \%$ of patients upon physical examination includingpallor and abdominal mass. Presence of a rectal mass was found in 50\% of patients and was the most commonly encountered sign. Approximately a quarter of the participants were overweight or obese with a mean BMI of $22.3 \pm 3.4$ $\mathrm{kg} / \mathrm{m} 2$.

Although blood indices such as total white blood cell count and platelet counts were within the normal range, anaemia was reported in $60.5 \%$ of the patients. Renal function and electrolyte levels were found to be within the normal ranges (Mean blood urea level was $24.8 \pm 7.7 \mathrm{mg} / \mathrm{dL}$, serum creatinine was $0.95 \pm 0.32 \mathrm{mg} / \mathrm{dL}$, $\mathrm{Na}+$ level was $138.9 \pm 3.7 \mathrm{mmol} / \mathrm{L}$ and $\mathrm{K}+$ level was $3.7 \pm$ $0.4 \mathrm{mmol} / \mathrm{L}$ ).

A single patient had a history of benign or malignant disease, namely an ovarian cyst. According to the records $10 \%$ of patients 
had a family history of benign or malignant tumors and $8 \%$ of schistosomiasis.

\subsection{Histology data}

Adenocarcinoma was the most prevalent histopathological type of cancerous tumor. The degrees of differentiation varied: $24.2 \%$ were well differentiated, $15.2 \%$ were poorly differentiation and $57.6 \%$ were moderately differentiated. Patient's $\leq 50$ years old had a lower prevalence of highly differentiated tumors, although this result was not statistically significant when compared to patients > 50 years old. The opposite was true for poorly differentiated tumors, where patients $\leq 50$ years had an increased prevalence of these tumors compared to patients $>50$ years with a significantly lower prevalence $(\mathrm{p}=0.02)$. This finding suggests that the tumors in the younger patients were more aggressive in nature (Table 1 ).

Table 1: Staging and Degree of Differentiation of Tumors in the Study Population

\begin{tabular}{|c|c|c|c|c|}
\hline Parameter & & $\begin{array}{l}\text { Patients } \leq 50 \\
\text { years }\end{array}$ & $\begin{array}{l}\text { Patients > } \\
50 \text { years }\end{array}$ & p-value \\
\hline \multicolumn{5}{|c|}{ Duke's Stage } \\
\hline & Stage B & $\begin{array}{l}7 / 12 \\
(58.3 \%)\end{array}$ & $\begin{array}{l}11 / 20 \\
(55.0 \%)\end{array}$ & 0.428 \\
\hline & Stage C & $\begin{array}{l}5 / 12 \\
(41.7 \%)\end{array}$ & $\begin{array}{l}9 / 20 \\
(45.0 \%)\end{array}$ & 0.428 \\
\hline \multicolumn{5}{|c|}{$\begin{array}{l}\text { Degree of } \\
\text { Differentiation }\end{array}$} \\
\hline & Highly & $\begin{array}{l}2 / 12 \\
(16.7 \%)\end{array}$ & $\begin{array}{l}6 / 20 \\
(30.0 \%)\end{array}$ & 0.200 \\
\hline & $\begin{array}{l}\text { Moderately } \\
\text { Poorly }\end{array}$ & $\begin{array}{l}6 / 12(50.0 \%) \\
4 / 12 \\
(33.3 \%)\end{array}$ & $\begin{array}{l}13 / 20 \\
(65.0 \%) \\
1 / 20(5.0 \%)\end{array}$ & 0.200 \\
\hline
\end{tabular}

$* * *$ statistically significant difference

With respect to the extent to which the tumors metastasized, Duke's stages A and D were not observed in the study patients. More than half $(54.6 \%)$ of the patients were Dukes' stage B with the rest classified as stage $C$. One patient could not be staged. Duke's stages B was diagnosed in $58.3 \%$ of patients $\leq 50$ years old and in $55 \%$ of patients $>50$ years of age. Duke's stage C was present in $41.7 \%$ and $45 \%$ of patients younger and older than 50 years of age, respectively.

\subsection{HLA class II}

The most frequent MHC class detected in the tumors were HLA DRB3 > HLA DRB4 > DR17 > DR7 (Table 2). The frequencies of the afore-mentioned antigens in blood were $75.8 \%, 27.3 \%$, $21.2 \%$ and $15.2 \%$, respectively (Table 2 ).

Irrespective of age, frequencies of expression of MHC antigens (HLA DRB3, HLA DRB4, DR17 and DR7) in blood, tumors and apparently normal tissues, were similar.

Expression of HLA DRB3 allele in peripheral blood was increased to $80 \%$ in patients $>50$ years old whereas an increase to $69.2 \%$ was noted in patients $\leq 50$ years old. The DRB3 expression was found to be lower in the tumors of patients in both age groups. The lowest expression of DRB3 was observed in apparently normal tissue; $38.5 \%$ in patients $\leq 50$ years and $55 \%$ in patients $>50$ years old. Expression of HLA-DR17 in patient's $\leq 50$ years old showed the same trend as HLA DRB3, with the highest level of expression being present in the blood $(30.8 \%)$ and lowest expression being found in normal tissue (7.7\%). HLA-DR17 expression followed a different pattern for patients $>50$ years old, where $15 \%$ were observed in tumors and blood and only $5 \%$ in apparently normal tissue (Table 3).

No significant differences in HLA DRB3 and DR7 distribution with respect to sex and age were found. A significant difference was however found with the Duke's stages of the tumors for the
DRB3 antigen ( $\mathrm{p}=0.002$; Table 4$)$ and for the DR7 antigen ( $\mathrm{p}=$ 0.04; Table 4). HLA DR17 expression in the peripheral blood differed significantly $(\mathrm{p}=0.04)$ from the degree of tumor differentiation (Table 4).

Table 2: The Frequencies of Different MHC Class II Antigens among CRC Patient's Blood, Tumor and Apparently Normal Tissues

\begin{tabular}{|c|c|c|c|c|c|}
\hline $\begin{array}{l}\text { MHC } \\
\text { anti- } \\
\text { gen }\end{array}$ & $\begin{array}{l}\text { Tu- } \\
\text { mors }\end{array}$ & $\begin{array}{l}\text { Apparent- } \\
\text { ly } \\
\text { Normal } \\
\text { Tissue }\end{array}$ & $\begin{array}{l}\text { Peripheral } \\
\text { Blood }\end{array}$ & $\begin{array}{l}\text { p-value } \\
\text { (differ- } \\
\text { ence } \\
\text { between } \\
\text { tumor and } \\
\text { normal) }\end{array}$ & $\begin{array}{l}\text { p-value } \\
\text { (differ- } \\
\text { ence } \\
\text { between } \\
\text { tumor and } \\
\text { blood) }\end{array}$ \\
\hline DRB3 & $\begin{array}{l}19 / 33 \\
(57.6 \%\end{array}$ & $\begin{array}{l}16 / 33 \\
(48.5 \%)\end{array}$ & $\begin{array}{l}25 / 33(75.8 \\
\%)\end{array}$ & 0.448 & 0.316 \\
\hline DRB4 & $\begin{array}{l}7 / 33 \\
(21.2 \% \\
)\end{array}$ & $\begin{array}{l}9 / 33 \\
(27.3 \%)\end{array}$ & $\begin{array}{l}9 / 33 \\
(27.3 \%)\end{array}$ & 0.421 & 0.421 \\
\hline DR17 & $\begin{array}{l}5 / 33 \\
(15.2 \% \\
)\end{array}$ & $\begin{array}{l}2 / 33 \\
(6.1 \%)\end{array}$ & $\begin{array}{l}7 / 33 \\
(21.2 \%)\end{array}$ & 0.194 & 0.386 \\
\hline DR7 & $\begin{array}{l}5 / 33 \\
(15.2 \% \\
\text { ) }\end{array}$ & $\begin{array}{l}4 / 33 \\
(12.1 \%)\end{array}$ & $5 / 33(15.2 \%)$ & 0.425 & 0.428 \\
\hline DR1 & $\begin{array}{l}3 / 33 \\
(9.1 \%)\end{array}$ & $\begin{array}{l}4 / 33 \\
(12.1 \%)\end{array}$ & $3 / 33(9.1 \%)$ & 0.268 & 0.500 \\
\hline DR4 & $\begin{array}{l}2 / 33 \\
(6.1 \%)\end{array}$ & $\begin{array}{l}4 / 33 \\
(12.1 \%)\end{array}$ & $1 / 33(3.0 \%)$ & 0.166 & 0.326 \\
\hline DR8 & $\begin{array}{l}3 / 33 \\
(9.1 \%)\end{array}$ & $\begin{array}{l}2 / 33 \\
(6.1 \%)\end{array}$ & $2 / 33(6.1 \%)$ & 0.356 & 0.356 \\
\hline DRB5 & $\begin{array}{l}2 / 33 \\
(6.1 \%)\end{array}$ & $1 / 33(3.0 \%$ & $1 / 33(3.0 \%)$ & 0.326 & 0.326 \\
\hline
\end{tabular}

Table 3: The Effects of Age on Expression of Different MHC Antigens on Blood

\begin{tabular}{lllll}
\hline $\begin{array}{l}\text { MHC } \\
\text { Antigens }\end{array}$ & Site & $\begin{array}{l}\text { Patients } \leq 50 \\
\text { years } \%\end{array}$ & $\begin{array}{l}\text { Patients }>50 \\
\text { years } \%\end{array}$ & p- value \\
\hline \multirow{3}{*}{ DRB3 } & Tumor & $53.8 \%$ & $60 \%$ & 0.363 \\
& Normal tissue & $38.5 \%$ & $55 \%$ & 0.167 \\
& Blood & $69.2 \%$ & $80 \%$ & 0.293 \\
& Tumor & $30.8 \%$ & $15 \%$ & 0.140 \\
DRB4 & Normal tissue & $15.4 \%$ & $35 \%$ & 0.107 \\
& Blood & $15.4 \%$ & $35 \%$ & 0.107 \\
& Tumor & $15.4 \%$ & $15 \%$ & 0.489 \\
DR17 & Normal tissue & $7.7 \%$ & $5 \%$ & 0.374 \\
& Blood & $30.8 \%$ & $15 \%$ & 0.140 \\
\hline
\end{tabular}

\section{Discussion}

Tumor growth has been reported to be affected by the different states of HLA expression.(JanewayCA Jr et al.2001). In various neoplasms, the extent of HLA expression has been associated with the degree of tumor differentiation and disease prognoses.(Janeway CA Jr et al.2001). However, this has been contradicted. This controversy appears to be ascribed to different tissue origins of the various tumors as well as to the heterogeneous expression of individual tumor cells. (Wintzer H et al.1990, Goepel JR et al.1991).

Our study population had twice as many males as females, which was in concordance with previously published data. (Gao R et al.2008 \&Abotchie PN et al.2012). It has been implied that estrogen has an influence in the development and progression of colon cancer thereby(Rath-Wolfson L et al .2012), affecting disease outcome. (Koo J H \& Rupert WL.2012, Majek O et al.2013).

Early onset of CRC is increasing in developing countries. (Zahir $M$ et al.2014) In the current study, approximately $40 \%$ of patients were younger than 50 years old, which presents a higher proportion for the age group detected by Wang et al. (Wang R et al .2015). This finding agreed with previously published reports on CRC in Sudanese patients, (Taha M et al .2015, Mohammed MM et al.2015 \&Abdalla A A et al.2007), as well as with reports on Nigerian patients. (Adesanya AA et al.2000). 
Table 4: Age, Sex, Tumor Stage and Differentiation with Respect to DR Antigen Distribution

\begin{tabular}{|c|c|c|c|c|c|c|c|}
\hline $\begin{array}{l}\text { Parame- } \\
\text { ter }\end{array}$ & & $\begin{array}{l}\text { Tu- } \\
\text { mor } \\
\text { DRB } \\
3\end{array}$ & p-value & $\begin{array}{l}\text { Tu- } \\
\text { mor } \\
\text { DR7 }\end{array}$ & $\begin{array}{l}\text { p- } \\
\text { val- } \\
\text { ue }\end{array}$ & $\begin{array}{l}\text { Bloo } \\
\text { d } \\
\text { DR1 } \\
7\end{array}$ & $\begin{array}{l}\text { p- } \\
\text { val- } \\
\text { ue }\end{array}$ \\
\hline \multirow[t]{2}{*}{ Sex } & Male & $\begin{array}{l}15 / 2 \\
3 \\
(65.2 \\
\%)\end{array}$ & $\begin{array}{l}0.0088 \\
5\end{array}$ & $\begin{array}{l}4 / 23 \\
(17.4 \\
\%)\end{array}$ & $\begin{array}{l}0.29 \\
50\end{array}$ & $\begin{array}{l}6 / 23 \\
(26.1 \\
\%)\end{array}$ & $\begin{array}{l}0.14 \\
92\end{array}$ \\
\hline & Female & $\begin{array}{l}4 / 10 \\
(40.0 \\
\%)\end{array}$ & & $\begin{array}{l}1 / 10 \\
(10.0 \\
\%)\end{array}$ & & $\begin{array}{l}1 / 10 \\
(10.0 \\
\%)\end{array}$ & \\
\hline \multirow{2}{*}{ Age } & $\begin{array}{l}\leq 50 \\
\text { years }\end{array}$ & $\begin{array}{l}7 / 13 \\
(53.8 \\
\%)\end{array}$ & 0.3632 & $\begin{array}{l}2 / 13 \\
(15.4 \\
\%)\end{array}$ & $\begin{array}{l}0.48 \\
80\end{array}$ & $\begin{array}{l}3 / 13 \\
(23.1 \\
\%)\end{array}$ & $\begin{array}{l}0.41 \\
68\end{array}$ \\
\hline & $\begin{array}{l}>50 \\
\text { years }\end{array}$ & $\begin{array}{l}12 / 2 \\
0 \\
(60.0 \\
\%)\end{array}$ & & $\begin{array}{l}3 / 20 \\
(15.0 \\
\%)\end{array}$ & & $\begin{array}{l}4 / 20 \\
(20.0 \\
\%)\end{array}$ & \\
\hline \multirow{2}{*}{$\begin{array}{l}\text { Duke's } \\
\text { stage }\end{array}$} & B & $\begin{array}{l}6 / 18 \\
(33.3 \\
\%)\end{array}$ & $\begin{array}{l}0.0015 \\
4 * * *\end{array}$ & $\begin{array}{l}1 / 18 \\
(5.6 \\
\%)\end{array}$ & $\begin{array}{l}0.04 \\
* * *\end{array}$ & $\begin{array}{l}3 / 18 \\
(21.4 \\
\%)\end{array}$ & 0.5 \\
\hline & $\mathrm{C}$ & $\begin{array}{l}12 / 1 \\
4 \\
(85.7 \\
\%)\end{array}$ & & $\begin{array}{l}4 / 14 \\
(28.6 \\
\%)\end{array}$ & & $\begin{array}{l}3 / 14 \\
(21.4 \\
\%)\end{array}$ & \\
\hline \multirow{3}{*}{$\begin{array}{l}\text { Degree } \\
\text { of differ- } \\
\text { entiation }\end{array}$} & Highly & $\begin{array}{l}4 / 8 \\
(50.0 \\
\%)\end{array}$ & 0.4522 & $0 / 8$ & $\begin{array}{l}0.11 \\
70\end{array}$ & $\begin{array}{l}1 / 8 \\
(12.5 \\
\%)\end{array}$ & $\begin{array}{l}0.04 \\
* * *\end{array}$ \\
\hline & $\begin{array}{l}\text { Mod- } \\
\text { erately }\end{array}$ & $\begin{array}{l}10 / 1 \\
9 \\
(52.6 \\
\%)\end{array}$ & & $\begin{array}{l}3 / 19 \\
(15.8 \\
\%)\end{array}$ & & $\begin{array}{l}2 / 19 \\
(10.5 \\
\%)\end{array}$ & \\
\hline & Poorly & $\begin{array}{l}4 / 5 \\
(80.0 \\
\%)\end{array}$ & & $\begin{array}{l}2 / 5 \\
(40.0 \\
\%)\end{array}$ & & $\begin{array}{l}3 / 5 \\
(60.0 \\
\%)\end{array}$ & \\
\hline Total & & $\begin{array}{l}19 / 3 \\
3 \\
(57.6 \\
\%)\end{array}$ & & $\begin{array}{l}5 / 33 \\
(15.2 \\
\%)\end{array}$ & & $\begin{array}{l}7 / 33 \\
(21.2 \\
\%)\end{array}$ & \\
\hline
\end{tabular}

***statistically significant difference

The results of this study are like those from the Far East which found that the most common histological type of tumor found in CRC are well or moderately differentiated mucinous, adenocarcinomas.(Matsushita K et al .2006). Furthermore, the anatomical sites of the tumors (rectum or recto-sigmoid) are similar to the current findings.

All cases in this study were diagnosed as Duke's stage B or C, with the absence of stage A and D seen. This is in contrast to studies from the East where Duke' stages A and D were reported (Matsushita K et al.1996).This difference may be due to the advanced nature of CRC in Sudanese patients. This explains the higher percentages of Duke's C and D. (Mohammed MM et al.2015). The absence of patients with Duke's stage $A$ is in line with our hypothesis that states that Sudanese colorectal cancer is aggressive.

An increased expression of the HLA DR antigen at the cell surface is seen as a marker for immune stimulation. HLA DRB3 was highly expressed in the DNA samples obtained from blood compare to other sites especially for older patients (> 50 years) while those patients also showed low expression of HLA DR17. HLA DRB3 was also present in high frequencies in blood, tumors as well as apparently normal tissues in older patients ( $>50$ years) compared with younger patients ( $\leq 50$ years). Generally, DR17 frequencies were very low compared to DRB3, with their lowest frequency in apparently normal tissues followed by tumors and blood respectively.

HLA-DR antigens are responsible for tumor-associated antigen recognition by CD4+ T cells. (Zeh HJ et al.2001)HLA-DR antigens are expressed on healthy colorectal epithelium, (Mayer L et al.1991) but are present in colorectal epithelium of inflammatory bowel disease as well as in cancer cells. This is due to the effects of interferon-- $\gamma($ IFN-- $\gamma)$ Which may or may not be acting in combination with tumor necrosis factor (TNF)- $\alpha$. (Satoh A et al.2004). Patients with poorly differentiated adenocarcinoma had a higher amount of HLA DR17 in their blood compared to tumor tissue. The normal tissues showed an absence of HLA DR17. With regard to the highly-differentiated adenocarcinoma, no HLA DR17 was detected in the tumor tissue, and no significant difference was found in HLA DR17 frequency in blood and apparently normal tissue.

A higher amount of HLA DR7 antigen was found in patients with Duke's stage C cancer compared to those with Duke's stage B cancer $(p=0.04)$, The HLA DR7 antigen was not detected in highly differentiated tumors and only an insignificant amount of the antigen was found in the poorly differentiated tumors. The HLA DR7 antigen was not detected in the apparently normal tissues of patients with poorly differentiated adenocarcinomas.

In the peripheral blood samples, no difference in antigen concentration was found between different degrees of tumor differentiation.

No significant difference in HLA DRB4, DR7, DR17 and DR1 antigen expression in blood, tumor and apparently normal tissue samples was detected. These findings are contradictory to that of McDougall CJ et al (McDougall CJ et al.1990), where a significant reduction in the expression of HLA class II antigens in colonic carcinomas, as compared to control colon mucosa, was found. These authors stated that the expression of HLA class II antigens may vary from colon mucosa obtained from healthy individuals as well as on a histologically healthy colon mucosa obtained from patients with colon cancer. Furthermore, a lack of expression of HLA-DR antigens in healthy colon tissue, with an increased expression in CRC tissues due to IFN- $\gamma$ It has been reported. (Masahiro lizuka et al.1990), On the contrary, a decreased HLA-DR antigen expression in cancer cells, but increased expression in adjacent non-cancerous tissues has been reported. (Matsushita K et al.2006, Tamiolakis D et al.2005).

HLA DRB3 antigen expression was higher in the peripheral blood of patients $>50$ years old compared to those $\leq 50$ years old, while HLA DR17 expression was higher in the blood of young patients, $\leq 50$ years compared to tumors and apparently normal mucosa. Neither of these differences, however, were found to be statistically significant. The variable expression levels of the selected HLAclass alleles are widely reflected in literature, and the results can be attributed to the gradual down regulation of these alleles. (Dierssen JW et al.2006). The similarities found between the tumor and apparently normal tissues may be due to the fact that apparently normal tissue is not healthy tissue and may be part of the neoplastic transformation spectrum as was previously described. (Facista A et al.2012).

The extent of HLA-DR and -DP expression on the colorectal cancerous tissues has been found to be inversely proportional to the degree of tumor differentiation. (Masahiro Iizuka et al.1990). This was found to be true for the DR17 antigen which was found in the highest amounts in the peripheral blood of patients with poorly differentiated adenocarcinomas. However, no significant increase in the frequencies of HLA-DRB3 or DR7 in patients with poorly differentiation adenocarcinoma compared to those with well differentiated ones was found. This result may be due to the small sample size of the current study.

The higher expression level of DRB3 and DR7 in tumors with Duke's stage $\mathrm{C}$ compared to stage $\mathrm{B}$ is in line with what was reported by Matsushita et al. (Matsushita K et al.2006). It has been shown that patients with Dukes Stages C and D, and a high HLADR antigen expression in cancer cells have a significantly better prognosis compared to those with weak HLA-DR expression. (Masahiro Iizuka et al.1990).

The lack of correlation between HLA-DRB3 and DR7 expression and the degree of differentiation shown in this study has previously been described. (McDougall CJ et al.1990)).Also, no correlation with Duke's stages and HLA-DR-expression was described by these authors. 


\section{Conclusion}

This study found that CRC affected a larger number of people under the age of 50 years old than what has previously been stated in literature. CRC tumors tended to become more aggressive in advanced Duke's stages. This aggressive nature may be attributed to increasing HLA DRB3 and DR7 antigen expression or decreasing HLA DR17 antigen expression in the tumor tissues.

\section{Acknowledgments}

The study was supported by the Department of Clinical Pathology and Immunology, Institute of Endemic Diseases, University of Khartoum. We thank all patients and their families for their participation in this study, also we would like to thank Ms. Omima Abdul-Aziz / Researcher, University of Khartoum for her technical support in the lab.

\section{References}

[1] World Health Organization. The Global Burden of Disease: 2004 Update. Geneva: World Health Organization 2008. https://doi.org/10.3322/caac.20138.

[2] Siegel R, Naishadham D, Jemal A. Cancer statistics, 2012. CA Cancer J Clin 2012 Jan-Feb; 62:10-29. doi: 10.3322/caac.20138.

[3] Matanoski G, Tao X, Almon L, Adade AA, Davies-Cole JO. Demographics and tumor characteristics of colorectal cancers in the United States, 1998-2001. Cancer. 2006; 107: 1112-1120. https://doi.org/10.1002/cncr.22008.

[4] Saeed E I, Hsin-Yi Weng, Mohamed K H and Mohammed SI. Cancer incidence in Khartoum, Sudan: first results from the Cancer Registry, 2009-2010. Cancer Med 2014 Aug; 3: 1075-1084. doi: 10.1002/cam4.254. https://doi.org/10.1002/cam4.254.

[5] Menon AG, Janssen-van Rhijn CM, Morreau H, Putter H, Tollenaar RA, van de Velde CJ, Fleuren GJ, Kuppen PJ. Immune system and prognosis in colorectal cancer: a detailed immunohistochemical analysis. Lab Invest 2004; 84: 493-501. https://doi.org/10.1038/labinvest.3700055.

[6] Cavallo F, De GC, Nanni P, Forni G, Lollini PL. The immune hallmarks of cancer. Cancer Immunol Immunother 2011; 60: 319326. https://doi.org/10.1007/s00262-010-0968-0.

[7] Shunyakov L, Ryan CK, Sahasrabudhe DM, Khorana AA. The influence of host response on colorectal cancer prognosis. Clin Colorectal Cancer 2004; $1: 38-45$ https://doi.org/10.3816/CCC.2004.n.008.

[8] Giuseppe VM, Emilia Andersson, Lisa Villabona, Hildur Helgadottir ,Kjell Bergfeldt, Federica Cavallo, et al. Survival of the fittest or best adapted: HLA-dependent tumor development. Journal of Nucleic Acids Investigation 2010; 10.4081. doi:10.4081/jnai.2010.

[9] Giuseppe S, Serenella E, Inti Z, Eva K, Roberto A, Andrea C, Sara Caratelli et.al. HLA Class II Antigen Expression in Colorectal Carcinoma Tumors as a Favorable Prognostic Marker. Neoplasia 2014 Jan; 16: 31-42.doi.org/10.1593/neo.131568.

[10] Daar AS, Fuggle SV, Fabre JW, Ting A, Morris PJ. The detailed distribution of MHC class II antigens in normal human organs. Transplantation1984; 38:293. https://doi.org/10.1097/00007890198409000-00019.

[11] De Bruin EC, van de Velde CJ, van Krieken JH, Marijnen CA, and Medema JP. Epithelial human leukocyte antigen-DR expression predicts reduced recurrence rates and prolonged survival in rectal cancer patients. Clin Cancer Res 2008; 14, 1073-1079. https://doi.org/10.1158/1078-0432.CCR-07-1597.

[12] Lazzaro B, Anderson AE, Kajdacsy-Balla A, and Hessner MJ. Antigenic characterization of medullary carcinoma of the breast: HLADR expression in lymph node positive cases. Appl Immunohistochem Mol Morphol 2001; 9, 234-241. https://doi.org/10.1097/00129039-200109000-00007.

[13] Taramelli D, Fossati G, Mazzocchi A, Delia D, Ferrone S, and Parmiani G. Classes I and II HLA and melanoma-associated antigen expression and modulation on melanoma cells isolated from primary and metastatic lesions. Cancer Res 1986; 46, 433-439.

[14] Lovig T, Andersen SN, Thorstensen L, Diep CB, Meling GI, Lothe RA, and Rognum TO. Strong HLA-DR expression in microsatellite stable carcinomas of the large bowel is associated with good prog- $\begin{array}{llllll}\text { nosis. } & \mathrm{Br} & \mathrm{J} & \text { Cancer } & 2006 ; & 87,\end{array}$ https://doi.org/10.1038/sj.bjc.6600507.

[15] Moller P, Momburg F, Koretz K, Moldenhauer G, Herfarth C, Otto HF, Hämmerling GJ and Schlag P. Influence of major histocompatibility complex class I and II antigens on survival in colorectal carcinoma. Cancer Res 1991; 51, 729-736.

[16] Mulder WM, Stern PL, Stukart MJ, de Windt E, Butzelaar RM, Meijer S, et al. Low intercellular adhesion molecule 1 and high 5T4 expression on tumor cells correlate with reduced disease-free survival in colorectal carcinoma patients. Clin Cancer Res 1997; 3, 1923-1930.

[17] Diederichsen AC, Hjelmborg J, Christensen PB, Zeuthen J, and Fenger C. Prognostic value of the $\mathrm{CD} 4+/ \mathrm{CD} 8+$ ratio of tumour infiltrating lymphocytes in colorectal cancer and HLA-DR expression on tumour cells. Cancer Immunol Immunother 2003; 52, 423 -428. https://doi.org/10.1007/s00262-003-0388-5.

[18] Bruce A Roe, Judy S. Crabtreeand Akbar S. Khan, DNA Isolation and Sequencing in Essential Techniques Series 1996, Published by John Wiley \& Sons, ISBN 0-471-97324.

[19] Janeway CA Jr, Travers P, Walport M, Shlomchik M J. functions". In Immunobiology, 5th edn,New York: Garland Science, 2001.

[20] Wintzer HO, Benzing M, von Kleist S. Lacking prognostic significance of 2-microglobulin, MHC class I and class II antigen expression in breast carcinomas. BrJ Cancer 1990; 289-295. https://doi.org/10.1038/bjc.1990.280.

[21] Goepel JR, Rees RC, Rogers K, Stoddard CJ, Thomas WEG, Shepherd L. Loss of monomorphic and polymorphic HLA antigens in metastatic breast and colon carcinoma. Br J Cancer 1991; 880-883. https://doi.org/10.1038/bjc.1991.418.

[22] Gao R N, Neutel C I, Wai E. Gender differences in colorectal cancer incidence, mortality, hospitalization and surgical procedures in Canada. J Public health 2008.30:194-201. https://doi.org/10.1093/pubmed/fdn019.

[23] Abotchie PN, Vernon SW, Du XL. Gender differences in colorectal cancer incidence in the United State, 1975-2006. J Women's Health 2012; 21: 393-400. https://doi.org/10.1089/jwh.2011.2992.

[24] Rath-Wolfson, L O, Purim O, Ram E, Morgenstern S, Koren R, Brenner B. "Expression of estrogen receptor betal in colorectal cancer: correlation with clinicopathological variables." Oncol Rep 2012; 27: 2017-2022. https://doi.org/10.3892/or.2012.1712.

[25] Koo J H \& Rupert WL. Sex differences in epidemiological, clinical and pathological characteristics of colorectal cancer. Journal of Gastroenterology and Hepatology 2010; 33-42.

[26] Majek O, Gondos A, Jansen L, Emrich K, Holleczek B, Katalinic A, et al. Sex Differences in Colorectal Cancer Survival: PopulationBased Analysis of 164,996 Colorectal Cancer Patients in Germany. PLoS ONE 2013; 8: https://doi.org/10.1371/journal.pone.0068077.

[27] Zahir M N, Azhar E M, Rafig S, Ghias K and Shabbir M. Clinical features and outcome of sporadic colorectal carcinoma in young patients: a cross sectional analysis from developing country. ISRN Oncol 2014; 46-1570. https://doi.org/10.1155/2014/461570.

[28] Wang R, Wang M J \& Pinge J. Clinicopathological Features and Survival Outcomes of Colorectal Cancer in Young versus Elderly: A Population-Based Cohort Study of SEER 9 Registries Data (1988-2011) Medicine (Baltimore) 2015; 94: e1402. https://doi.org/10.1097/MD.0000000000001402.

[29] Taha MO, Abdalla AA, and Mohamed R S. Pattern \& presentation of colorectal cancer in central Sudan, a retrospective descriptive study, 2010-2012, Afr Health Sci 2015; 15: 576-580 https://doi.org/10.4314/ahs.v15i2.3.

[30] Mohammed MM, Musaad A M, Eltayeb E and Abdalaziz M. Colorectal Carcinoma in Sudanese Patients. International Journal of Medicine 2015; 3: 98-102. https://doi.org/10.14419/ijm.v3i2.5159.

[31] Abdalla A A, Musa MT \& Khair R Z. Presentation of Colorectal Cancer in Khartoum Teaching Hospital.Sudan JMS 2007; 2: 263-65.

[32] Adesanya AA, da Rocha-Afodu JT. Colorectal cancer in Lagos: a critical review of 100 cases. Niger Postgrad Med J 2000; 7: 129_ 136. https://doi.org/10.3748/wjg.14.6531.

[33] Matsushita K, Takenouchi T, Kobayashi S, Hayashi H, Okuyama K, Ochiai $\mathrm{T}$ et al. HLA-DR antigen expression in colorectal carcinomas: influence of expression by IFN- $\gamma$ in situ and its association with tumour progression. Br J Cancer 1996; 73: 644-8.

[34] Zeh HJ, Stavely-O'Carroll K, Choti MA. Vaccines for colorectal cancer. Trends Mol Med 2001; 7: 307-13.doi.org/10.1016/S14714914 (01)01992-X

[35] Mayer L, Eisenhardt D, Salomon P, Bauer W, Plous R, Piccinini L. Expression of class II molecules on intestinal epithelial cells in humans. Differences between normal and inflammatory bowel disease. 
Gastroenterology 1991; 100: 3-12. https://doi.org/10.1016/00165085(91)90575-6.

[36] Satoh A, Toyota M, Ikeda H, Morimoto Y, Akino K, Mita H et al. Epigenetic inactivation of class II transactivator (CIITA) is associated with the absence of interferongamma- induced HLA-DR expression in colorectal and gastric cancer cells. Oncogene 2004; 23 : 8876-86. https://doi.org/10.1038/sj.onc.1208144.

[37] McDougall CJ, Ngoi SS, Goldman IS, Godwin T, Felix J, DeCosse JJ, et al. Reduced Expression of HLA Class I and II Antigens in Colon Cancer. CANCER RESEARCH 1990; 50: 8023-8027.

[38] Masahiro Iizuka, Mitsuro Chiba, Yasuo Horie, Osamu Masamune and Hiromasa Ohta. Lymphoid cell subsets in colonie mucosa and HLA-DR antigens on colonic epithelia in colitis excluding ulcerative colitis and crohn's disease. Gastroenterologia Japonica 1990; 25-700.

[39] Matsushita K, Takenouchi T, Shimada H, Tomonaga T, Hayashi H, Shioya A, et al. "Strong HLA-DR antigen expression on cancer cells relates to better prognosis of colorectal cancer patients: Possible involvement of c-myc suppression by interferon-gamma in situ. Cancer Sci 2006; 57-63.

[40] Tamiolakis D, Venizelos J, Papadopoulos N, Lambropoulou M, Papadopoulos E, Simopoulos C. Expression of HLA-DR antigen and characterization of the lymphocytic infiltrate in normal mucosa, tubullovillous adenoma and invasive carcinoma of the colon. Chirurgia 2005; 100: 451-456.

[41] Dierssen JW, de Miranda NF, Mulder A, van Puijenbroek M, Verduyn W, Claas FH, et.al. High resolution analysis of HLA class I alterations in colorectal cancer. BMC Cancer 2006; 6: 233. https://doi.org/10.1186/1471-2407-6-233.

[42] Facista A, Nguyen H, Lewis C, Prasad AR, Ramsey L, Zaitlin B, et al. Deficient expression of DNA repair enzymes in early progression to sporadic colon cancer. Genome Integr. 2012; 11:3:3 https://doi.org/10.1186/2041-9414-3-3. 